\title{
Eksekusi Hak Tanggungan dalam Perjanjian Pembiayaan
}

\author{
Sobirin, Junaidi \\ IAIN Kudus, IAIN Kudus \\ sobirin@gmail.com, abdillahrafandra@gmail.com
}

\begin{abstract}
$B M T$ both in the form of KJKS and KSPS in providing loans and financing can be in the form of Mudhorobah, Murobahah or Musyarokah, usually KJKS and KSPS parties make the conditions in the form of collateral. Goods that are used as collateral can be in the form of movable or immovable objects. When collateral is in the form of a moving object (usually in the form of a motorcycle or car), the KJKS and KSPS will make a fiduciary guarantee and when the collateral is in the form of immovable property (usually in the form of land or house), the KSPS and KJKS will dependents. When a member who carries out a broken promise, the KSPS Logam Mulia party can execute directly the Underwriting Right object. However, the KSPS Logam Mulia sub-district of Klambu, Grobogan, did not directly execute the object of collateral rights. The mortgages in the KSPS Logam Mulia sub-district in Klambu, Grobogan Regency were carried out to bind the collateralized object to guarantee the immovable property such as land or land along with the building on it. KSPS Logam Mulia does not execute directly on objects that are pledged as collateral rights, but through sales voluntarily or ask for help to sell.

Keywords: Execution, Mortgage Rights, Financing Agreement
\end{abstract}

\begin{abstract}
Abstrak
BMT baik dalam bentuk KJKS maupun KSPS dalam memberikan peminjaman maupun pembiayaan bisa berupa Mudhorobah, Murobahah maupun Musyarokah, bisanya pihak KJKS maupun KSPS membetikan persyaratan berupa barang jaminan atau yang bisa disebut juga dengan agunan. Barang yang dijadikan agunan atau jaminan tersebut bisa berupa benda bergerak maupun benda tidak bergerak. Ketika barang jaminan atau agunan berupa benda bergerak (biasanya berupa sepeda motor atau mobil) maka pihak KJKS maupun KSPS akan membuat jaminan fidusia dan ketika yang dijaminkan berupa benda tidak bergerak (biasanya berupa tanah maupun rumah), maka pihak KSPS maupun KJKS akan mendaftarkannya dengan hak tanggungan. Ketika anggota yang melakukan pembiayaan ingkar janji, maka pihak KSPS Logam Mulia bisa mengeksekusi langsung obyek Hak Tanggungan. Akan tetapi pihak KSPS Logam Mulia kecamatan Klambu kabupaten Grobogan tidak mengeksekusi langsung obyek jaminan Hak Tanggungan. Hak tanggungan yang ada di KSPS Logam Mulia kecamatan Klambu Kabupaten Grobogan dilakukan untuk mengikat benda yang dijaminkan untuk melakukan pembiayaan dengan jaminan benda tidak bergerak seperti tanah atau tanah beserta bangunan yang ada di atasnya. Pihak KSPS Logam Mulia tidak melakukan eksekusi secara langsung terhadap obyek yang dijaminkan dengan hak tanggungan, melainkan melalui penjualan secara suka rela atau minta bantuan dijualkan.
\end{abstract}

Kata Kunci : Eksekusi, Hak Tanggungan, Perjanjian Pembiayaan

\section{PENDAHULUAN}

Lembaga keuangan syariah merupakan lembaga keuangan yang ada dengan tujuan mengembangkan dunia perbankan, koperasi maupun 
lembaga keuangan lainnya, lembaga-lembaga tersebut operasionalnya menggunakan prinsip-prinsip syari'ah. Andri soemitra dalam bukunya Bank dan Lembaga Keuangan Syari'ah menyatakan, bahwa prinsip syari'ah adalah prinsip hukum Islam dalam kegiatan perbankan dan keuangan berdasarkan fatwa yang dikeluarkan oleh lembaga yang memiliki kewenangan dalam penetapan fatwa di bidang syari'ah, prinsip syari'ah yang dianut oleh lembaga keuangan syari'ah dilandasi oleh nilai-nilai keadilan, kemanfaatan, keseimbangan dan keuniversalan (rahmatan lil'alamin). (Andri Soemitra, 2012: 36).

Lembaga keuangan syariah yang ada di Indonesia, bisa berbentuk perbankan syariah, asuransi syariah, koperasi syariah atau BMT. Sedangkan BMT itu sendiri bisa berbentuk Koperasi Jasa Keuangan Syariah (KJKS) dan bisa juga berupa Koperasi Simpan Pinjam Syariah (KSPS). BMT baik yang berupa KJKS maupun KSPS tentu mempunyai produk-produk simpanan/ penghimpunan dana maupun pinjaman atau pembiayaan.

Bentuk penghimpunan dana langsung dari masyarakat bisa berupa tabungan, deposito maupun produk-produk lainnya. Sedangkan dalam menyalurkan dana ke masyarakat, lembaga keuangan syariah membuat produk-produk pembiayaan seperti mudhorobah, musyarokah maupun murobahah. Dalam penyaluran dana kepada masyarakat atau anggotanya, biasanya akan diikat dengan perjanjian/aqad. Kegiatan lembaga keuangan syari'ah baik bank maupun non bank dalam penyaluran dana terjadi suatu hubungan hukum antara kreditur dengan debitur yang dituangkan dalam perjanjian kredit. Perjanjian kredit dalam istilah hukum perdata adalah hukum perjanjian atau kontrak. Lawrence M. Friedman dalam bukunya Salim H.S. yang berjudul Hukum Kontrak menyatakan hukum kontrak adalah perangkat hukum yang hanya mengatur aspek tertentu dari pasar dan mengatur jenis perjanjian tertentu (Salim Hs, 2006: 3).

BMT baik dalam bentuk KJKS maupun KSPS dalam memberikan peminjaman maupun pembiayaan bisa berupa Mudhorobah, Murobahah maupun Musyarokah, bisanya pihak KJKS maupun KSPS memberikan persyaratan berupa barang jaminan atau yang bisa disebut juga dengan agunan. Barang yang dijadikan agunan atau jaminan tersebut bisa berupa benda bergerak maupun benda tidak bergerak. Ketika barang jaminan atau agunan berupa benda bergerak (biasanya berupa sepeda motor atau mobil) maka pihak KJKS maupun KSPS akan membuat jaminan fidusia dan ketika yang dijaminkan berupa benda tidak bergerak (biasanya berupa tanah maupun rumah), maka pihak KSPS maupun KJKS akan mendaftarkannya dengan hak tanggungan.

Hak tanggungan adalah hak jaminan yang dibebankan pada hak atas tanah sebagaimana dimaksud dalam Undang-Undang Nomor 5 
Tahun 1960 tentang Peraturan Dasar Pokok-Pokok Agraria, berikut atau tidak berikut benda-benda lain yang merupakan satu kesatuan dengan tanah itu, untuk pelunasan utang tertentu, yang memberikan kedudukan yang diutamakan kepada kreditor tertentu terhadap kreditor-kreditor lain (Pasal 1 ayat 1 Undang Undang Nomor 4 tahun 1996 tentang hak Tanggungan Atas Tanah Beserta Benda Benda Yang Berkaitan Dengan Tanah).

Hak atas tanah yang dapat dibebani hak tanggungan adalah:

a. Hak Milik

b. Hak Guna Usaha

c. Hak Guna Bangunan.

Hak tanggungan dapat juga dibebankan pada hak atas tanah berikut bangunan, tanaman, dan hasil karya yang telah ada atau akan ada yang merupakan satu kesatuan dengan tanah tersebut, dan yang merupakan milik pemegang hak atas tanah yang pembebanannya dengan tegas dinyatakan di dalam Akta Pemberian Hak Tanggungan yang bersangkutan (Undang Undang Nomor 4 tahun 1996 tentang hak Tanggungan Atas Tanah Beserta Benda Benda Yang Berkaitan Dengan Tanah).

Apabila bangunan, tanaman, dan hasil karya seperti tersebut di atas tidak dimiliki oleh pemegang hak atas tanah, pembebanan hak tanggungan atas benda-benda tersebut hanya dapat dilakukan dengan penandatanganan serta pada Akta Pemberian hak tanggungan yang bersangkutan oleh pemiliknya atau yang diberi kuasa untuk itu olehnya dengan akta otentik.

KSPS Logam Mulia merupakan salah satu BMT di Kabupaten Grobogan yang besar dan mempunyai banyak cabang. Ketika menyalurkan dana kepada anggotanya tentu dengan cara melakukan pembiayaan. Ketika melakukan pembiayaan ini, anggotanya harus memberikan jaminan. Ketika jaminan berupa benda bergerak, maka akan di buatkan akta jaminan fidusia dan ketika jaminan berupa tanah maupun rumah, maka akan di ikat dengan hak tanggungan.

Kadangkala, anggota KSPS Logam Mulia ada yang bisa memberikan prestasi dengan cara membayar angsuran dan ada pula yang tidak mampu membayarnya, sehingga pembiayaannya menjadi macet. Secara hukum, ketika ada anggota dari sebuah BMT yang tidak mampu membayar angsurannya, maka pihak BMT bisa mengeksekusi jaminan berupa tanah maupun bangunanya dengan cara pelelangan.

Menurut Retnowulan Sutantio dan Iskandar Oeripkartawinata menyatakan, bahwa Eksekusi adalah Tindakan paksaan oleh Pengadilan terhadap pihak yang kalah dan tidak mau melaksanakan putusan dengan sukarela (Retnowulan Sutantio dan Iskandar Oeripkartawinata, 1997 : 10). Ketika jaminan berupa tanah, maka akan diikat dengan hak 
tanggungan yang didaftarkan dikantor pertanahan dengan dibuatkan sertifikat hak tanggungan yang memuat titel eksekutorial yang berbunyi "Demi Keadilan Berdasarkan Ketuhanan Yang Maha Esa". Eksekusi hak tanggungan bisa dilakukan oleh kreditur, apabila debitur melakukan wanprestasi dengan melakukan penjualan di balai lelang Negara. Artinya, pihak KSPS Logam Mulia bisa melaksanakan eksekusi terhadap benda yang dijaminkan. Namun, fakta yang ada, eksekusi hak tanggungan yang seharusnya dapat dilakukan oleh KSPS Logam Mulia kecamatan Klambu kabupaten Grobogan ternyata tidak dilaksanakan.

Menurut Wahyu Pratama, dalam jurnal Ilmu Hukum Legal Opinion Edisi 6 Volume 3 tahun 2015 dengan judul Tinjauan Hukum Tentang Sertifikat Hak Tanggungan Menurut Undang Indang Nomor 4 tahun 1996, menyatakan bahwa obyek jaminan (benda yang dijaminkan), yang telah di ikat dengan hak tanggungan, maka ketika debitur wanprestasi, secara hukum obyek yang dijadikan agunan bisa di eksekusi oleh pihak kreditur. Karena dalam sertifikat hak tanggungan memuat title eksekusi (Wahyu Pratama, 2015 : 1-8).

Sedangkan menurut Jamilus dalam lurnal De Jure, dengan judul penelitian Persoalan Dalam Pelaksanaan Eksekusi Sertifikat dan Hak tanggungan. bahwa obyek yang menjadi hak tanggungan bisa dieksekusi melalui parate eksekusi, artinya kreditur bisa mengambil obtek yang di agunkan dengan hak tanggungan kemudian menjualnya tanpa bantuan pihak pengadilan negeri. Hanya meminta bantuan kantor lelang Negara saja (Jumalis, 2017: 283-299).

Selanjutnya menurut Anis Mashdurrohatun, Zaenal Arifin dan Gunarto, didalam International journal of Applied Business and Economic Research dengan judul The Inconsistency of Parate Execution Object Warranty og Rigth In Banking Credit Agrement in Indonesia, mereka menyatakan bahwa ada ketidak konsistenan dalam parate eksekusi dalam benda jaminan hak milik yang dijadikan agunan dalam perbankan di Indoseia, yakini menggunakan Kantor Lelang Negara dan melibatkan Pengadilan Negeri (Anis Mashdurrohatun, Zaenal Arifin dan Gunarto, 2017: 267-281).

Berdasarkan beberapa penelitian di atas, maka ada perbedaan yang signifikan dengan penelitian ini, yakni terletak pada pelaksanaan eksekusi hak tanggungan, kalau penelitian lainnya mengatakan bahwa eksekusi hak tanggungan bisa dilakukan secara langsung karena ada title eksekutoril, sedangkan penelitian ini KSPS Logam Mulia tidak melaksanakan eksekusi hak tanggungan.

\section{KAJIAN LITERATUR}

Secara bahasa, kontrak bisa berasal dari bahasa Inggris "contracts", dan dalam bahasa Belanda dinamakan "oveenkomst" (Johannes Ibrahim Linda Sewu, 2004 : 42-43). Kalau dalam Bahasa Arab dinamakan mu'ahadah ittifa' 
atau akad" (Chairuman Pasaribu \& Suhrawadi K Lubis, 2004 : 1). Akad juga mempunyai banyak makna, seperti mengikat, sambungan dan janji (Abdul Rahman Ghazaly, 2015;.51). Menurut R. Setiawan perjanjian diartikan dengan suatu perbuatan hukum, di mana satu orang atau lebih mengikatkan dirinya atau saling mengikatkan dirinya terhadap satu orang atau lebih (R. Setiawan, $1979: 49)$.

\section{Syarat-Syarat Perjanjian}

Menurut pasal 1320 KUHPerdata kontrak adalah sah bila memenuhi syarat-syarat sebagai berikut :

Syarat subyektif, meliputi:

1) Kecakapan untuk membuat kontrak (dewasa dan tidak sakit ingatan)

2) Kesepakatan mereka yang mengikatkan dirinya.

Syarat obyektif, meliputi :

1) Suatu hal (obyek) tertentu

2) Sesuatu sebab yang halal (kuasa).

\section{Wanprestasi}

Ketika para pihak melaksanakan apa yang ada dalam perjanjian maka itu dinamakan prestasi, yang disebut prestasi dalam KUHPerdata pasal 1234 adalah seseorang yang menyerahkan sesuatu, melakukan sesuatu dan dan tidak melakukan sesuatu yang diperjanjikan. Dalam perjanjian (kontrak) terkadang ada perselisihan-perselisihan, perselisihan ini dikarenakan ada salah satu pihak yang tidak melaksanakan apa yang diatur dalam perjanjian (kontrak), dan ini dinamakan wanprestasi. Bentuk-bentuk wanprestasi :

1. Tidak melakukan apa yang disanggupi akan dilakukannya

2. Melaksanakan apa yang dijanjikannya, tetapi tidal sebagaimana dijanjikan

3. Melakukan apa yang dijanjikan tetapi terlambat

4. Melakukan sesuatu yang menurut perjanjian (kontrak) tidak boleh dilakukannya.

\section{Pembiayaan}

Pembiayaan atau financing yaitu pendanaan yang diberikan oleh suatu pihak kepada pihak lain untuk mendukung investasi yang telah direncanakan, baik dilakukan sendiri maupun lembaga. Dengan kata lain pembiayaan adalah pendanaan yang dikeluarkan untuk mendukung investasi yang telah direncanakan (Muhammad, 2008 : 16).

\section{Eksekusi Hak Tanggungan}

Menurut Subekti, yang dimaksud dengan eksekusi adalah upaya dari pihak yang dimenangkan dalam putusan guna mendapatkan yang 
menjadi haknya dengan bantuan kekuatan hukum, memaksa pihak yang dikalahkan untuk melaksanakan putusan (Subekti, 1989 : 128)..

Sedangkan menurut Ridwan Syahrani, yang dimaksud dengan eksekusi adalah realisasi dari kewajiban dari pihak yang kalah untuk memenuhi suatu kewajiban yang merupakan hak dari pihak yang menang, seperti yang tercantum dalam putusan pengadila (Ridwan Syahrani, 1988: 106).

Eksekusi adalah sebagai tindakan hukum yang dilakukan oleh pengadilan kepada pihak yang kalah dalam suatu perkara, eksekusi merupakan acuan dari proses pemeriksaan perkara, oleh karena itu eksekusi merupakan tindakan yang berkesinambungan dan keseluruhan proses hukum antara perdata. Jadi eksekusi merupakan suatu kesatuan yang tidak terpisahkan dari pelaksanaan tata tertib berita acara yang tertulis dalam HIR atau RBg (M. Yahya Harahap, 1988: 1).

Sedangkan yang dimaksud dengan hak tanggungan menurut Undang-Undang Nomor 4 Tahun 1996 Tentang Hak Tanggungan adalah hak jaminan yang dibebankan pada hak atas tanah sebagaimana dimaksud dalam Undang - Undang Nomor 5 Tahun 1960 tentang Peraturan Dasar Pokok-Pokok Agraria, berikut atau tidak berikut bendabenda lain yang merupakan satu kesatuan dengan tanah itu, untuk pelunasan utang tertentu, yang memberikan kedudukan yang diutamakan kepada kreditor tertentu terhadap kreditor-kreditor yang lain (Pasal 1 ayat 1 Undang-Undang Nomor 4 Tahun 1996 Tentang Hak Tanggungan),

\section{Obyek dan Subyek Hak Tanggungan}

Obyek hak tanggungan adalah berupa Hak atas tanah berupa Hak Milik, Hak Guna Usaha dan Hak Guna Bangunan. Sedangkan subyek dari Hak Tanggyngan adalah :

1. Pemberi hak tanggungan, yaitu orang perseorangan atau badan hukum yang mempunyai kewenangan untuk melakukan perbuatan hukum terhadap obyek Hak Tanggungan yang bersangkutan.

2. Pemegang hak tanggungan adalah orang perseorangan atau badan hukum yang berkedudukan sebagai pihak yang berpiutang. (UndangUndang Nomor 4 Tahun 1996 Tentang Hak Tanggungan),

\section{Tata Cara Penberian Hak Tanggungaan}

Pemberian hak tanggungan didahului dengan janji untuk memberikan Hak Tanggungan sebagai jaminan pelunasan utang tertentu, yang dituangkan di dalam dan merupakan bagian tak terpisahkan dari perjanjian utang-piutang yang bersangkutan atau perjanjian lain-nya yang menimbulkan utang tersebut. 
Pemberian hak tanggungan dilakukan dengan pembuatan Akta Pemberian Hak Tanggungan oleh PPAT sesuai dengan peraturan perundang-undangan yang berlaku.

Apabila obyek hak tanggungan berupa hak atas tanah yang berasal dari konversi hak lama yang telah memenuhi syarat untuk didaftarkan akan tetapi pendaftaran-nya belum dilakukan, pemberian hak tanggungan di-lakukan bersamaan dengan permohonan pendaftaran hak atas tanah yang bersangkutan. (Undang Undang Nomor 4 tahun 1996 tentang Hak Tanggungan Atas Tanah Beserta Benda Benda Yang Berkaitan Dengan Tanah),

Di dalam Akta Pemberian Hak Tanggungan wajib dicantumkan

1. Nama dan identitas pemegang dan pemberi hak tanggungan

2. Domisili pihak-pihak pemegang dan pemberi hak tanggungan dan apabila di antara mereka ada yang berdomisili di luar Indonesia, baginya harus pula dicantumkan suatu domisili pilihan di Indonesia, dan dalam hal domisili pilihan itu tidak dicantumkan, kantor PPAT tempat pembuatan Akta Pemberian Hak Tanggungan dianggap sebagai domisili yang dipilih

3. Penunjukan secara jelas utang atau utang-utang yang dijamin

4. Nilai tanggungan

5. Uraian yang jelas mengenai obyek hak tanggungan.

Dalam Akta Pemberian Hak Tanggungan dapat dicantumkan janji-janji, antara lain :

a. Janji yang membatasi kewenangan pemberi hak tanggungan untuk menyewakan obyek hak tanggungan dan/atau menemukan atau mengubah jangka waktu sewa dan/atau menerima uang sewa di muka, kecuali dengan persetujuan tertulis lebih dahulu dari pemegang hak tanggungan

b. Janji yang membatasi kewenangan pemberi hak tanggungan untuk mengubah bentuk atau tata susunan obyek hak tanggungan, kecuali dengan persetujuan tertulis lebih dahulu dari pemegang hak tanggungan

c. Janji yang memberikan kewenangan kepada pe-megang hak tanggungan untuk mengelola obyek hak tanggungan berdasarkan penetapan Ketua Pengadilan Negeri yang daerah hukumnya meli-puti letak obyek hak tanggungan apabila debitor sungguhsungguh cidera janji

d. Janji yang memberikan kewenangan kepada pemegang hak tanggungan untuk menyelamatkan obyek hak tanggungan, jika hal itu diperlukan untuk pelaksanaan eksekusi atau untuk mencegah menjadi hapusnya atau dibatalkannya hak yang menjadi obyek hak tanggungan karena tidak dipenuhi atau dilanggarnya ketentuan undang undang 
e. Janji bahwa pemegang Hak Tanggungan pertama mempunyai hak untuk menjual atas kekuasaan sendiri obyek hak tanggungan apabila debitor cidera janji

f. Janji yang diberikan oleh pemegang hak tanggungan pertama bahwa obyek hak tanggungan tidak akan dibersihkan dari hak tanggungan

g. Janji bahwa pemberi hak tanggungan tidak akan melepaskan haknya atas obyek hak tanggungan tanpa persetujuan tertulis lebih dahulu dari peme-gang Hak Tanggungan

h. Janji bahwa pemberi hak tanggungan tidak akan melepaskan haknya atas obyek Hak Tanggungan tanpa persetujuan tertulis lebih dahulu dari peme-gang hak tanggungan

i. Janji bahwa pemegang hak tanggungan akan memperoleh seluruh atau sebagian dari ganti rugi yang diterima pemberi hak tanggungan untuk pelunasan piutangnya apabila obyek hak tanggungan dilepaskan haknya oleh pemberi Hak Tanggungan atau dicabut haknya untuk kepen-tingan umum

j. Janji bahwa pemegang hak tanggungan akan memperoleh seluruh atau sebagian dari uang asuransi yang diterima pemberi hak tanggungan untuk pelunasan piutangnya, jika obyek hak tanggungan diasuransikan

k. Janji bahwa pemberi hak tanggungan akan me-ngosongkan obyek Hak Tanggungan pada waktu eksekusi hak tanggungan

1. J anji yang Kecuali apabila diperjanjikan lain, sertipikat hak atas tanah yang telah dibubuhi catatan pembebanan Hak Tanggungan (Undang Undang Nomor 4 tahun 1996 tentang Hak Tanggungan Atas Tanah Beserta Benda Benda Yang Berkaitan Dengan Tanah),

Pembebanan hak tanggungan merupakan suatu proses yang terdiri atas 2 tahap kegiatan, yaitu : Tahap pemberian hak tanggungan, yaitu dengan dibuatnya APHT oleh Pejabat Pembuat Akta Tanah, yang didahului dengan perjanjian utang-piutang yang dijamin. Tahap pendaftaran oleh Kantor Pertanahan, yang merupakan saat lahirnya Hak Tanggungan yang dibebankan (Purwahid Patrik dan Kashadi, 2006 : 62)..

\section{Pendaftaran Hak Tanggungan}

Pemberian hak tanggungan wajib didaftarkan pada Kantor Pertanahan. Selambat-lambatnya 7 (tujuh) hari kerja setelah penandatanganan Akta Pemberian Hak Tanggungan, PPAT wajib mengirimkan Akta Pemberian Hak Tanggungan yang bersangkutan dan warkah lain yang diperlukan kepada Kantor Pertanahan.

Pendaftaran hak tanggungan dilakukan oleh Kantor Pertanahan dengan membuatkan buku tanah hak tanggungan dan mencatatnya dalam buku tanah hak atas tanah yang menjadi obyek hak tanggungan serta menyalin catatan tersebut pada sertipikat hak atas tanah yang 
bersangkutan. Tanggal buku tanah hak tanggungan adalah tanggal hari ketujuh setelah penerimaan secara lengkap surat-surat yang di-perlukan bagi pendaftarannya dan jika hari ketujuh itu jatuh pada hari libur, buku tanah yang bersangkutan diberi bertanggal hari kerja berikutnya. Hak tanggungan lahir pada hari tanggal buku tanah hak tanggungan diberikan yakni hari ketujuh.

Sebagai tanda bukti adanya hak tanggungan, Kantor Pertanahan menerbitkan sertipikat hak tanggungan sesuai dengan peraturan perundang-undangan yang berlaku. Sertipikat hak tanggungan memuat irah-irah dengan kata-kata "DEMI KEADILAN BERDASARKAN KETUHAN-AN YANG MAHA ESA".

Sertipikat hak tanggungan mempunyai kekuatan eksekutorial yang sama dengan putusan pengadilan yang telah memperoleh kekeuatan hukum tetap dan berlaku sebagai pengganti grosse acte Hypotheek sepanjang mengenai hak atas tanah. Kecuali apabila diperjanjikan lain, sertipikat hak atas tanah yang telah dibubuhi catatan pembebanan hak tanggungan dikembalikan kepada pemegang hak atas tanah yang bersangkutan. Sertipikat hak tanggungan diserahkan kepada pemegang hak tanggungan (Undang Undang Nomor 4 tahun 1996 tentang Hak Tanggungan Atas Tanah Beserta Benda Benda Yang Berkaitan Dengan Tanah).

\section{Eksekusi Hak Tanggungan}

Dengan debitur yang ingkar janji, maka kreditur bisa langsung mengeksekusi benda jaminan yang dijaminkan hak tanggungan. Karena di dalam sertifikat Hak Tanggungan memuat ketentuan kata-kata " Demi Keadilan Berdasarkan Ketuhanan Yang Maha Esa". Dengan kata-kata ini, maka mempunyai kekuatan hukum seperti keputusan pengadilan.

Apabila debitor cidera janji, maka eksekusi dapat dilakukan berdasarkan :

a. Hak pemegang hak tanggungan pertama untuk menjual obyek Hak Tanggungan

b. Titel eksekutorial yang terdapat dalam sertipikat hak tanggungan obyek hak tanggungan dijual melalui pelelangan umum menurut tata cara yang ditentukan dalam peraturan perundang-undangan untuk pelunasan piutang pemegang Hak Tanggungan dengan hak mendahulu dari pada kreditor-kreditor lainnya (Undang Undang Nomor 4 tahun 1996 tentang Hak Tanggungan Atas Tanah Beserta Benda Benda Yang Berkaitan Dengan Tanah.

Atas kesepakatan pemberi dan pemegang hak tanggungan, penjualan obyek hak tanggungan dapat dilaksanakan di bawah tangan jika dengan demikian itu akan dapat diperoleh harga tertinggi yang menguntungkan semua pihak. 
Pelaksanaan penjualan hanya dapat dilakukan setelah lewat waktu 1 (satu) bulan sejak diberitahukan secara tertulis oleh pemberi dan/atau pemegang hak tanggungan kepada pihak-pihak yang berkepentingan dan diumumkan sedikit-dikitnya dalam 2 (dua) surat kabar yang beredar di daerah yang bersangkutan dan/atau media massa setempat, serta tidak ada pihak yang menyata-kan keberatan.

Setiap janji untuk melaksanakan eksekusi hak tanggungan dengan cara yang bertentangan dengan ketentuan yang berlaku batal demi hukum. Sampai saat pengumuman untuk lelang dikeluarkan, penjualan dapat dihindarkan dengan pelunasan utang yang dijamin dengan hak tanggungan itu beserta biaya-biaya eksekusi yang telah dikeluarkan. Apabila pemberi Hak Tanggungan dinyatakan pailit, pemegang hak tanggungan tetap berwenang melakukan segala hak yang diperolehnya.

\section{PEMBAHASAN}

\section{Hak Tanggungan di KSPS Logam Mulia Kecamatan Klambu Kabupaten Grobogan}

Hak tanggungan yang ada di KSPS Logam Mulia dilakukan untuk mengikat benda yang dijaminkan untuk melakukan pembiayaan dengan jaminan benda tidak bergerak seperto tanah atau tanah beserta bangunan yang ada di atasnya. Hak Tanggungan meupakan hasil dari perjanjian antara anggota dengan KSPS Logam Mulia kecamatan Klambu kabupaten Grobogan untuk sebuah pembiayaan.

Perjanjian (kontrak) adalah suatu peristiwa dimana dua orang atau lebih saling berjanji untuk melakukan atau tidak melakukan perbuatan tertentu, yang biasanya secara tertulis. Para pihak yang bersepakat untuk mentaati dan melaksanakannya, sehingga perjanjian tersebut menimbulkan hubungan hukum yang disebut perikatan (verbintenis).

Maka kontrak dapat menimbulkan hak dan kewajiban bagi para pihak yang membuat kontrak tersebut, karena itu kontrak yang mereka buat adalah sumber hukum formal, asal kontrak tersebut adalah kontrak yang sah (Abdul R Saliman, 2004 : 12). Dengan demiian perjanjian (kontrak) merupakan dasar hukum para pihak dalam menjalankan kerja sama bisnisnya selain acuan undang-undang.

Hak Tanggungan merupakan manifestasi perjanjian yang dilakukan oleh anggota dan KSPS Logam Mulia kecamatan Klambu Kabupaten Grobogan, sehingga perjanjian tersebut menimbulkan hak dan kewajiban kedua belah pihak.

Kewajiban kreditur dalam hal ini KSPS Logam Mulia memberi kewajiban untuk memberikan pembiayaan kepada anggotanya dan mempunyai hak untuk mendapatkan uang angsuran dari anggotanya. Sedangkan kewajiban anggota adalah membayar sejumlah angsuran 
akibat dari pembiayaan dan mempunyai hak untuk diberikan pembiayaan.

Untuk merealisasikan pembiayaan yang dilakukan oleh debitur sebagai anggota dan kreditur yakni KSPS Logam Mulia diperlukan benda jaminan. Ketika benda yang dijaminkan berupa tanah atau bangunan yang di atasnya maka akan diikat dengan Hak Tanggungan.

Hak tanggungan menurut Undang-Undang Nomor 4 Tahun 1996 Tentang Hak Tanggungan adalah hak jaminan yang dibebankan pada hak atas tanah sebagaimana dimaksud dalam Undang - Undang Nomor 5 Tahun 1960 tentang Peraturan Dasar Pokok-Pokok Agraria, berikut atau tidak berikut benda-benda lain yang merupakan satu kesatuan dengan tanah itu, untuk pelunasan utang tertentu, yang memberikan kedudukan yang diutamakan kepada kreditor tertentu terhadap kreditor-kreditor yang lain (Pasal 1 ayat 1 Undang-Undang Nomor 4 Tahun 1996 Tentang Hak Tanggungan). Hak atas tanah yang dapat dibebani Hak Tanggungan adalah Hak Milik, Hak Guna Usaha dan Hak Guna Bangunan.

Dari hak tanggungan yang ada pada KSPS Logam Mulia kecamatan Klambu Kabupaten Grobogan bila dikaitkan dengan syarat perjanjian, maka secara hukum sudah sesuai dengan aturan main yang berlaku di Indonesia, yakni dalam KUHPerdata disebutkan syarat untuk melakukan harus memenuhi syarat subyektif yakni anggota yang melakukan perjanjian pembiayaan bersepakat dengan KSPS Logam Mulia tanpa ada paksaan serta sudah dewasa. Sedangkan syarat yang selanjutnya adalah obyek perjanjian jelas dan isi perjanjian tidak bertentangan dengan norma-norma yang berlaku di dalam masyarakat.

Begitu juga obyek yang dijaminkan dalam hak tanggungan adalah berupa tanah atau bangunan yang menjadi hak milik dari anggota yang melakukan pembiayaan ke KSPS Logam Mulia kecamatan Klambu Kabupaten Grobogan.

Prosedur pembebanan dan pendaftaran juga sudah sesuai dengan Undang-Undang Hak Tanggungan pasal 10, yakni :

1. Pemberian Hak Tanggungan didahului dengan janji untuk memberikan Hak Tanggungan sebagai jaminan pelunasan utang tertentu, yang dituangkan di dalam dan merupakan bagian tak terpisahkan dari perjanjian utang-piutang yang bersangkutan atau perjanjian lain-nya yang menimbulkan utang tersebut.

2. Pemberian Hak Tanggungan dilakukan dengan pembuatan Akta Pemberian Hak Tanggungan oleh PPAT sesuai dengan peraturan perundang-undangan yang berlaku.

3. Apabila obyek Hak Tanggungan berupa hak atas tanah yang berasal dari konversi hak lama yang telah memenuhi syarat untuk didaftarkan akan tetapi pendaftaran-nya belum dilakukan, pemberian Hak Tanggungan di-lakukan bersamaan dengan permohonan 
pendaftaran hak atas tanah yang bersangkutan (Undang Undang Nomor 4 tahun 1996 tentang Hak Tanggungan Atas Tanah Beserta Benda Benda Yang Berkaitan Dengan Tanah).

Hak Tanggungan yang dilakukan oleh KSPS Logam Mulia kecamatan Klambu kabupaten Grobogan sudah sesuai dengan hukum yang berlaku di Indonesia.

\section{Eksekusi Hak Tanggungan di KSPS Logam Mulia Kecamatan Klambu Kabupaten Grobogan}

Sebagai tanda bukti adanya hak tanggungan, Kantor Pertanahan menerbitkan sertipikat hak tanggungan atas permohonan kreditur.. Sertipikat Hak Tanggungan tersebut memuat irah-irah dengan kata-kata "DEMI KEADILAN BERDASARKAN KETUHAN-AN YANG MAHA ESA". Sertipikat Hak Tanggunan yang tertulis kalimat di atas mempunyai kekuatan eksekutorial yang sama dengan putusan pengadilan yang telah memperoleh kekeuatan hukum tetap dan berlaku sebagai pengganti grosse acte Hypotheek sepanjang mengenai hak atas tanah.

Eksekusi dapat dilakukan berdasarkan :

a. Hak pemegang Hak Tanggungan pertama untuk menjual obyek Hak Tanggungan

b. Titel eksekutorial yang terdapat dalam sertipikat Hak Tanggungan obyek Hak tanggungan dijual melalui pelelangan umum menurut tata cara yang ditentukan dalam peraturan perundang-undangan untuk pelunasan piutang pemegang Hak Tanggungan dengan hak mendahulu dari pada kreditor-kreditor lainnya.

Eksekusi bisa dilakukan Ketika anggota KSPS Logam Mulia Kecamatan Klambu Kabupaten Grobogan melakukan wanprestasi atau ingkar janji, seperti tidak melakukan apa yang disanggupi akan dilakukannya (tidak membayar angsuran), melaksanakan apa yang dijanjikannya, tetapi tidak sesuai yang dijanjikan, melakukan apa yang dijanjikan tetapi terlambat dan melakukan sesuatu yang menurut perjanjian tidak boleh dilakukannya

Pihak KSPS Logam Mulia tidak melakukan eksekusi secara langsung terhadap obyek yang dijaminkan dengan hak tanggungan melalui pelelangan, melainkan melalui penjualan secara suka rela atau minta bantuan untuk dijualkan.

Atas kesepakatan pemberi dan pemegang hak tanggungan, penjualan obyek hak tanggungan dapat dilaksanakan di bawah tangan jika dengan demikian itu akan dapat diperoleh harga tertinggi yang menguntungkan semua pihak.

Pelaksanaan penjualan hanya dapat dilakukan setelah lewat waktu 1 (satu) bulan sejak diberitahukan secara tertulis oleh pemberi dan/atau 
pemegang Hak Tanggungan kepada pihak-pihak yang berkepentingan dan diumumkan sedikit-dikitnya dalam 2 (dua) surat kabar yang beredar di daerah yang bersangkutan dan/atau media massa setempat, serta tidak ada pihak yang menyata-kan keberatan.

Setiap janji untuk melaksanakan eksekusi Hak Tanggungan dengan cara yang bertentangan dengan ketentuan yang berlaku batal demi hukum. Sampai saat pengumuman untuk lelang dikeluarkan, penjualan dapat dihindarkan dengan pelunasan utang yang dijamin dengan Hak Tanggungan itu beserta biaya-biaya eksekusi yang telah dikeluarkan. Apabila pemberi Hak Tanggungan dinyatakan pailit, pemegang Hak Tanggungan tetap berwenang melakukan segala hak yang diperolehnya.

Secara hukum, apa yang dilakukan oleh KSPS Logam Mulia sudah sesuai dengan Undang-Undang Hak Tanggungan yang pada poin kedua dan langkah lainnya yang membedakan dengan lembaga keuangan lainnya.

\section{KESIMPULAN}

Setelah diadakan pembahasan, maka dapat disimpulkan, bahwa :

1. Bahwa Hak Tanggungan yang ada di KSPS Logam Mulia dilakukan untuk mengikat benda yang dijaminkan untuk melakukan pembiayaan dengan jaminan benda tidak bergerak seperti tanah atau tanah beserta bangynan yang ada di atasnya.

2. Bahwa pihak KSPS Logam Mulia tidak melakukan eksekusi secara langsung terhadap obyek yang dijaminkan dengan Hak Tanggungan, melainkan melalui penjualan secara suka rela.

\section{DAFTAR PUSTAKA}

Abdul Rahman Ghazaly, dkk. (2015) Fiqh Muamalat. Jakarta: Prenada Media.

Abdul R, Saliman. 2004. Hukum Bisnis Untuk Perusahaan teori dan contoh kasus. Jakarta : Kencana.

Advensi Simangusong, Eli Kartika Sari. 2004. Hukum dalam Ekonomi, Jakarta : Grassindo.

Andri Soemitra.. 2012 Bank dan Lembaga Keuangan Syari'ah. Jakarta : Kencana Prenada Media Group.

Chairuman Pasaribu \& Suhrawadi K Lubis. 2004. Hukum Perjanjian. Jakarta : Sinar Grafika.

International journal of Applied Business and Economic Research dengan judul The Inconsistency of Parate Execution Object Warranty og Rigth In Banking Credit Agrement in Indonesia, Volume 15, Number 20, 2017

Jurnal Ilmu Hukum Legal Opinion, Edisi 6 Volume 3 tahun 2015

Jurnal Penelitian Hukum, De Jure, Volume 17 Nomor 2, Juni 2017 (Terakreditasi LIPPI) 
Jurnal Repoerterium, Volume III Nomor 2 Juli-Desember 2016 Kitab Undang Undang Hukum Perdata

M. Yahya Harahap. 1998. Ruang Lingkup Permasalahan Eksekusi Bidang Perdata. Jakarta : PT. Gramedia.

Muhammad. 2008. Manajemen Pembiayaan Bank Syariah. Yogyakarta : UPP AMP YKPN.

R. setiawan. 1979. Pokok Pokok Hukum Perikatan. Bandung : Binacipta.

Renowulan Sutantio dan Iskandar Oeripkartawinata. 1997. Hukum Acara Perdata Dalam Teori dan Praktek. Bandung : PT. Mandar Maju.

Subekti. 1984. Hukum Perjanjian. Jakarta : Intermasa.

Satrio. 1992. Hukum Perjanjian. Bandung : Citra Aditya Bakti.

Salim Hs. 2006. Hukum Kontrak. Jakarta : Sinar Grafika.

Undang Undang Nomor 4 tahun 1996 tentang Hak Tanggungan Atas Tanah Beserta Benda Benda Yang Berkaitan Dengan Tanah

Veithzal Rivai. 2008. Islamic Financial Management. Jakarta : Raja Grafindo Persada. 